Komunike, Volume XI, No. 2, Desember 2019

\title{
DINAMIKA MEDIA KOMUNIKASI SEBAGAI INTERAKSI POLITIK
}

\author{
Priska Nur Safitri \\ UIN Walisongo Semarang \\ priscanasafitri07@gmail.com
}

\begin{abstract}
Abstrak
Kekuatan media dalam komunikasi politik, menjadikan para aktoraktor politik, dan partainya membentuk opini publik yang memmpengaruhi masyarakat. Era kecepatan informasi saat ini masyarakat dituntut untuk berfikir kritis supaya tidak terpengaruh oleh opini yang salah dan merugikan. Membangun citra untuk mendapatkan kekuasaan ditingkatkan agar dikenal positif masyarakat sebagai sarana branding. Hadirnya internet atau new media menguatkan aktor politik untuk menyebarkan konten demi popularitasnya naik. Maka sudah seharusnya ada regulasi terutama dalam ranah maya karena penyebarannya yang cepat, harus bener-benar mengawasi media. Supaya realitas dari media untuk menyampaikan informasi dalam hal ini politik tidak kehilangan esensinya.
\end{abstract}

Kata Kunci: Media, Komunikasi, Interaksi Politik 
Komunike, Volume XI, No. 2, Desember 2019

\section{A. Latar Belakang}

Berbicara tentang politik tidak terlepas dari kekuatan (power) dan kewenangan (authority)

dalam setiap pelaksanaan pengambilan keputusan. ${ }^{1}$ Aktivitas politik saat menjelang pemilu merupakan suatu hal yang tidak dapat dipisahkan dalam kehidupan manusia. Mengingat iklim demokrasi di Indonesia yang terbuka lebar. ${ }^{2}$ Mengingat aktivitas media sebagai personalisasi politik menyajikan berbagai macam untuk mempengaruhi publik sebagai kunci dalam bidang komunikasi politik. ${ }^{3}$ Saat ini media massa di

\footnotetext{
'Thomas, Tokan Pureklolan, Komunikasi Politik: Mempertahankan Integritas Akademisi, Politikus, dan Negarawan, (Jakarta: Gramedia Pustaka Utama, 2005 ), 3.

${ }^{2}$ Roni Tabroni, Etika Komunikasi Politik dalam Ruang Media Massa, dalam Jurnal IImu Komunikasi, Vol 10, No. 2, Agustus 2012, 106.

${ }^{3}$ Chisnau, R. Muldofa, New Media Dimenssion: Personalization of Politics Academy, of Sciencs and
} Indonesia tidak terlepas dri prinsip subjektivitas. Hal ini mengakibatkan jurnalis mengabaikan kode etik jurnalistik atau kode etik menjadi fleksibel. ${ }^{4}$

Media sebagai orientasi pilihan politik dalam sebuah Negara tidak terlepas dari politik media. Goal oriented behviour merupakan orientasi politik dari sebuah media. Dalam hal ini komunikator politik atau politisi jurnalis serta masyarakat merupakan aktor utama dalam proses politik. $^{5}$ Umumnya politik media dipahami dalam upaya mencari kebebasan informasi, kebebasan dalam menyampaikan ide pemikiran untuk

Economic, Pdf, hal. 6. Dalam http://eresources.perpusnas.go.id.

${ }^{4}$ Roni Tabroni, Jurnal IImu Komunikasi, Etika Komunikasi..., 109.

${ }^{5}$ Siti, Aminah, Politik Media, Demokrasi dan Media Politik, Pdf. Dalam Jurnal Unair http://journal.unair.ac.id/filerPDF/POLITIK $\% 20$ MEDIA,\%20\%20DEMOKRASI.pdf 
Komunike, Volume XI, No. 2, Desember 2019

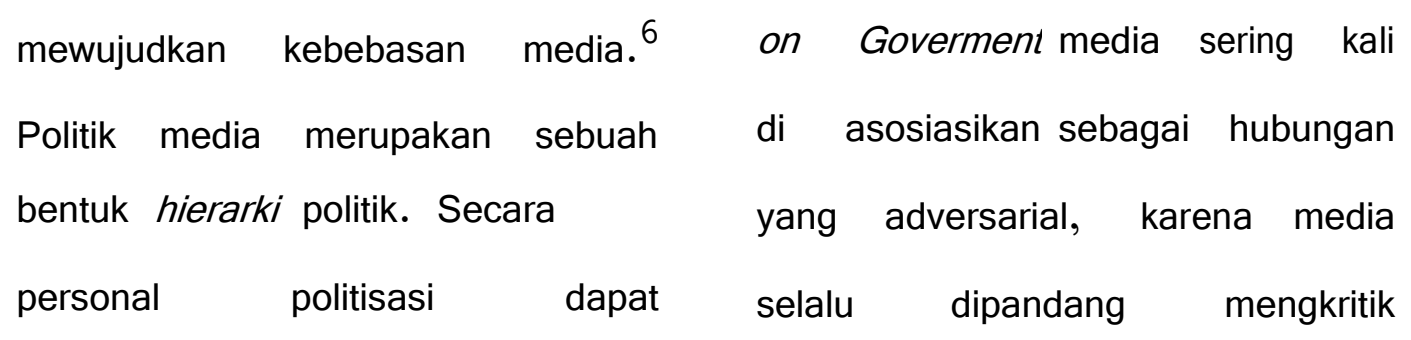

menambah ruang privat dan pemerintah. $^{8}$ Tiga pelaku dalam masyarakat sehingga mereka tetap politik media adalah politisi jurnalis bisa mengurusi politik meskipun ia maupun orang-orang yang tengah duduk di kursi jabatannya. digerakkan oleh kepentingan. Yaitu komunikasi yang menjangkau Politik media bagi politisi adalah sasaran masyarakat media komunitas untuk mobilitas massa. $^{7}$ dukungan masyarakat dalam Sikap dari politik media pemilu. Bagi jurnalis sebagai merepresentasikan pelaksanaan menulis berita sehingga kandidat manifestasi pilar ke empat terlibat konflik. Sementara demokrasi sebagai fungsi dari masyarakat sebagai wadah supaya media atau hubungan antara media kredibel, politisi akuntabel media dengan pemerintah. Sikap maupun sebagai pengawas politik. ${ }^{9}$ politik media merupakan cerminan dari ideologi nilai dan kepentingan yang ingin diperjuangkan. Check

\footnotetext{
${ }^{6}$ Hermin, Indah Wahyuni, Politik Media dalam Transisi Politik: Dari Kontrol Negara menuju Self Regulation Machanism, dalam Jurnal IImu Komunikasi, Vol. 04, No. 01, Juni 2007, 15.

${ }^{7}$ Siti, Aminah, Jurnal Unair, Politik Media...., 4 .
}

Media massa mengajak masyarakat untuk berfikir artinya media massa Indonesia dalam hal ini bertinndak sebagai pemberi

\footnotetext{
${ }^{8}$ Salvatore Simarmata, Media \& Politik: Sikap Pers terhadap Pemerintahan Koalisi di Indonesia, (Jakarta: Yayasan Pustaka Obor Indonesia, 2014), 23. ${ }^{9}$ Siti, Aminah, Jurnal Unair, Politik Media...., 6.
} 
Komunike, Volume XI, No. 2, Desember 2019

pendidikan dalam arti politik. hal penting yaitu mampu Sayangnya, kondisi di lapangan melakukan kritik dalam pemerintah media massa menyampaikan terlebih mereka yang punya informasi yang cenderung subjektif jabatan maupun pejabat politik baik dalam hal picture maupun lainnya. Karena sikap tersebut teks beritanya. Artinya para sebagai bentuk tindakan pemimpin media baik itu jurnalis maupun redaktur media masih independen atau otonom. ${ }^{11}$

Sikap politik media bisa terjadi punya peranan untuk menggiring atau mengarahkan publik dalam mengemas sebuah pesan yang berkepentingan dalam hal politik. $^{10}$

Politik media pada kesempatan ini secara khusus fokus pada oposisional. Norton menyebutkan bahwa sebuah hubungan yang standing in some from of disagreement to another body.

Ketidaksetujuan atau

(disagreement) merupakan bentuk penolakan atau kritisme terhadap sesuatu atau seseorang. Dalam menjalankan rolewatchdog, media diharapkan dapat melakukan dua

$\begin{array}{rrr}{ }^{10} \text { Roni } & \text { Tabroni, Jurnal } & \text { IImu } \\ \text { Komunikasi , Etika Komunikasi..., } & 110 .\end{array}$


Komunike, Volume XI, No. 2, Desember 2019

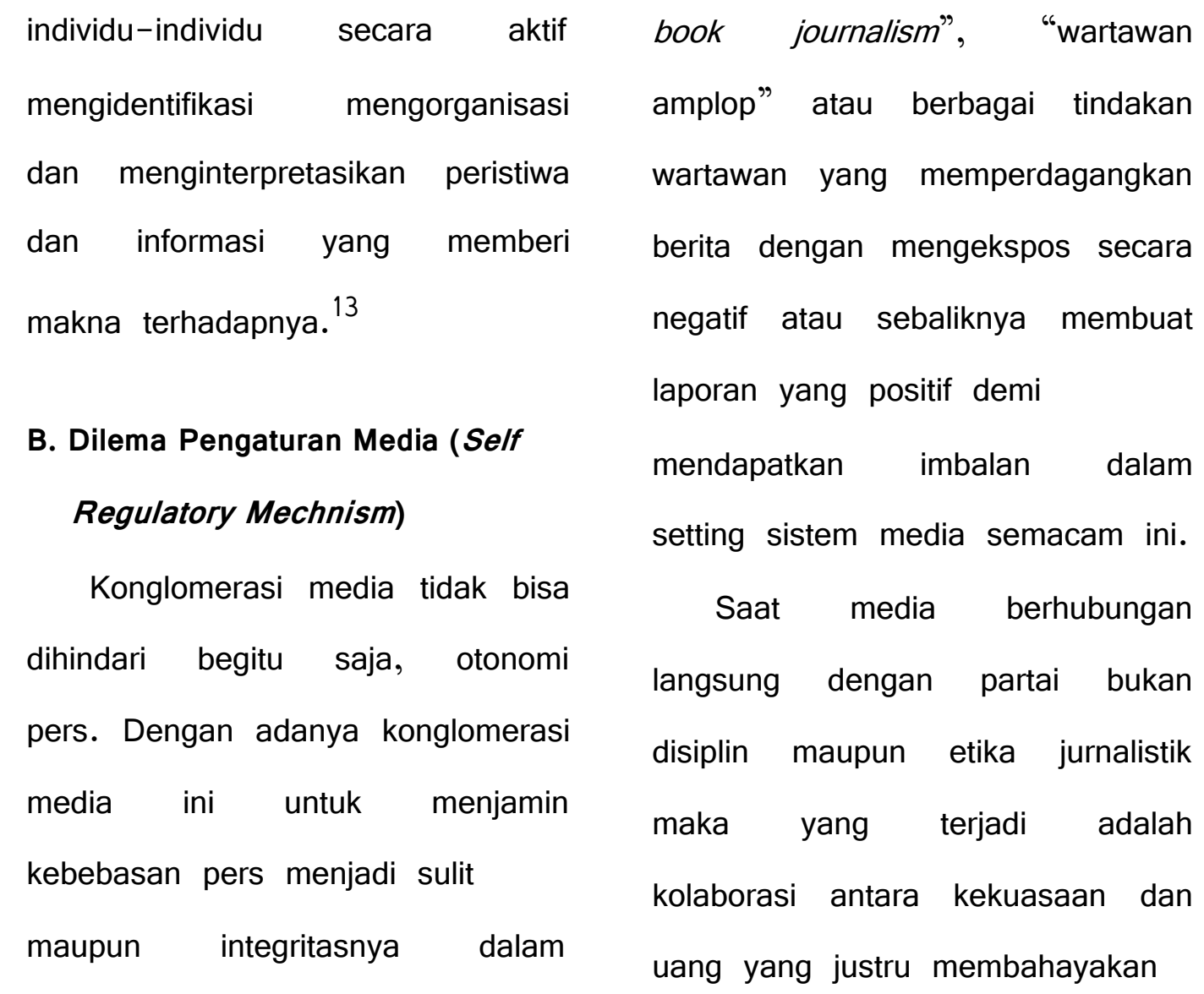

melakukan dalam melakukan

kebenaran. Dalam produksi media

sangat berkaitan dengan etika

jurnalistik. Misalnya: munculnya

finisme warga atau jurnalis tidak

melakukan save regulation

berkelindan dengan bisnis, untuk

berfikir dan menggunakan praktek

"good journalism" semakin sulit

direalisasikan selain itu "check

${ }^{13}$ Salvatore Simarmata, Media \&

pembangunan dalam praktek

jurnalisme yang sehat. Bagaimana yang dapat dilakukan dalam bentuk cicle setan seperti ini.

Melalui konsep politik media akan menjawab lingkaran setan dalam

adanya konglomerasi media.

Pertama, yaitu sisi politik media

sebagai kebijakan Negara. Dalam perspektif media politik yang pertama ini save regulation Politik:....,28. 
Komunike, Volume XI, No. 2, Desember 2019

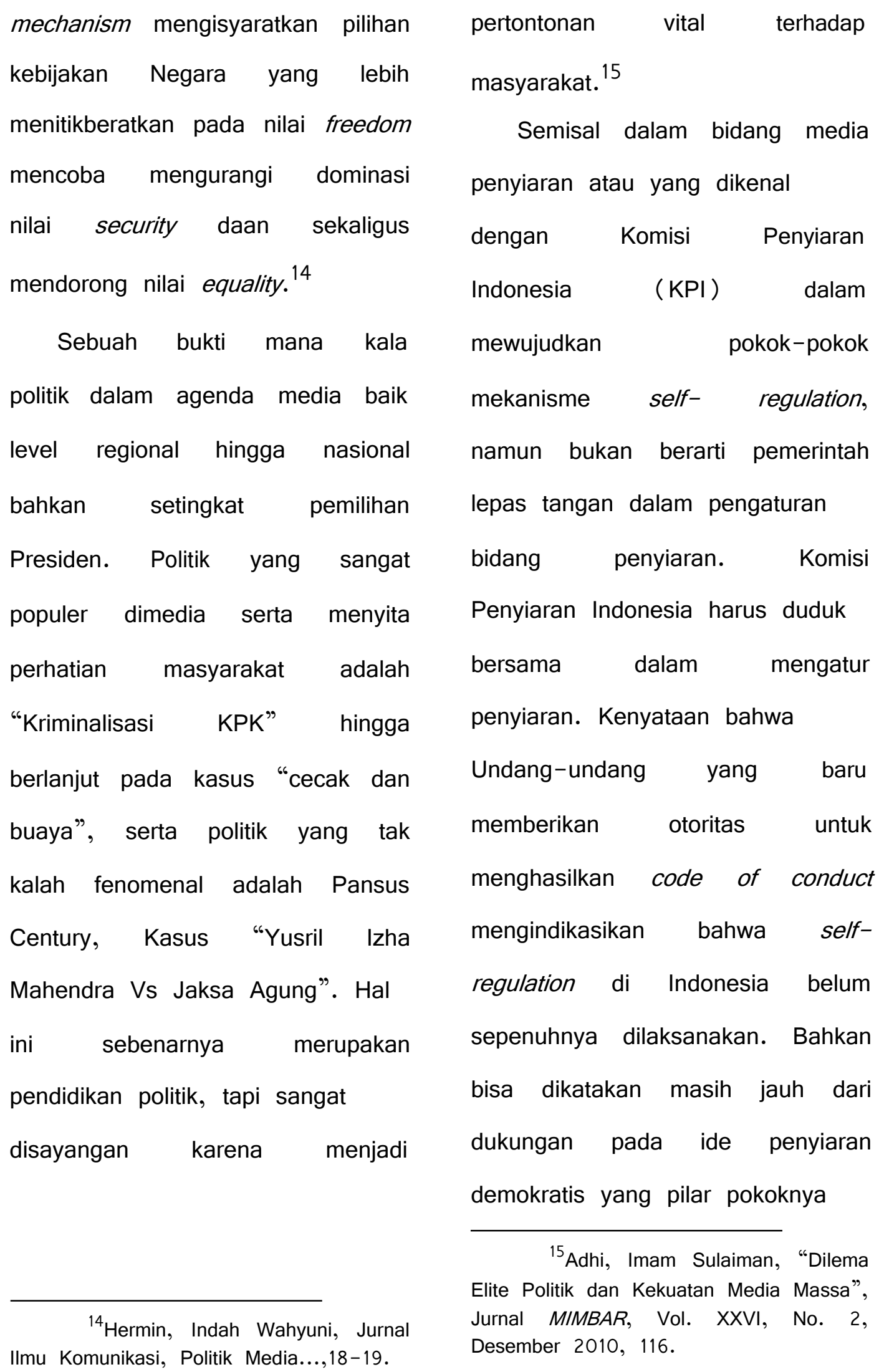
IImu Komunikasi, Politik Media...,18-19. 
Komunike, Volume XI, No. 2, Desember 2019

dalah terwujudnya self- regulation juga melahirkan sebuah pada lembaga penyiaran secara perundangan yang lebih bebas internal. dan memberikan respek yang kuat

Kedua, dari perspektif politik pada kebebasan untuk ber media sebagai bagian sistem pendaat. Sedangkan untuk bidang jaringan perilaku antar aktor penyiaran juga lahir Undang(pelaku) dapat dikatakan bahwa Undang beserta serangkaian dalam proses transisi menuju peraturan pemerintah yang demokrasi khususnya dalam bidang meimiliki karkater penyiaran media, masuknya aktor non-state demokratis yang cukup menonjol. dalam pengambilan kebijakan dan Fenomena ini menunjukkan bahwa dalam mekanisme

pengaturan media sangat masih lebih memberikan titik tekan menonjol. Di Indonesia, masih pada statutory mechanism dan dapat dilihat bahwa mekanisme bukan sebaliknya voluntary self-regulation bukanlah seuah mechannism. Walaupun demikian mekanisme penyelesaian utama pendekatan kedua (voluntary) dalam kasus pers ataupun ditandai dengan lahirnya aktor lain penyiaran. Karena pendekatan di luar Negara sebagai regulator statutori melalui perundangan penting dalam domain media formal masih lebih menonjol, baik massa ini. dalam kasus media cetak ataupun Ketiga, menggunakan media penyiaran. perspektif media politik sebagai Walaupun sebagai catatan konvergensi politik dapat dikatakan untuk kasus pers reformasi politik bahwapengaturan media massa di 
Indonesia masih dipandang lebih ekonomi dalam pengelolaan media terkait dengan bidang politik. Hal sebagai industri mendapat kajian ini bisa dilihat dari keberadaan komisi-komisi yang mengawangi media massa di parlemen yang selalu dipandang berdekatan dengan masalah politik, pertahanan, dan keamanan. Pandangan yang semacam ini membuat banyak kebijakan media massa di Indonesia lebih terkait dengan wacana politis. Dari aspek teknologi, sinergi multimedia membuat kebijakan media politik di Indonesia tidak memilik kekuatan "futuristic" yang
mengantisipasi cepatnya perubahan
dalam bidang ini. Hal ini dapat
dimengerti, khususnya bahwa
orang masih sulit melepaskan
pandangan bahwa media massa
merupakan aset politik, khusunya
karena sekian lama media massa
di fungsikan sebagai mesin
propaganda pemerintah. Aspek yang penting. ${ }^{16}$

Media sebagai saluran politik, yang memainkan "sikap", yang mendukung aktivitas politik, seyogyanya media memiliki etika dalam komunikasi politik dan ruang media yang mengedepankan kepentingan masyarakat. Masyarakat memperoleh informasi yang mencerdaskan serta objektif. Karena keterpihakan media pada politik terlalu mencolok, maka bukan tidak mungkin citra negatif media atas pemberitaan politik ada. $^{17}$

\section{Branding Politik Menggunakan Media sosial}

Saat ini kita masuk digenerasi ketiga dalam komunikasi

\footnotetext{
${ }^{16}$ Hermin, Indah Wahyuni, Jurnal IImu Komunikasi, Politik Media..., 2023.

${ }^{17}$ Roni Tabroni, Jurnal IImu Komunikasi, Etika Komunikasi...,114.
} 
Komunike, Volume XI, No. 2, Desember 2019

politik hal ini ditandai dengan politik. $^{19}$ Hal ini mengakibatkan perkembangan new media. Seiring produksi pesan maupun citra dengan menguatnya penggunaan politik sangat rentan untuk internet sebagai saran sosial "diganggu" akibat era interaktif (social network site) maupun ini. Para pelaku politik harus webblog interaktif. Saat ini memperhitungkan kemungkinan Indonesia termasuk pengguna pesan politik dimodifikasi oleh internet yang tinggi hal ini juga pihak lain karena, pesan tersebut tak terlepas dari para aktor politik, disampaikan melalui media sosial. baik politisi (wakil maupun Karena di era digitalisasi setiap ideologi ) figur politik, birokrat, informasi yang sudaah aktivis kelompok kepentingan

dipublikasikan ke publik secara (interest group), kelompok online maka siapapun dapat penekan (pressure group) mengaksesnya juga bebas untuk maupun wartawan media yang memodifikasi.

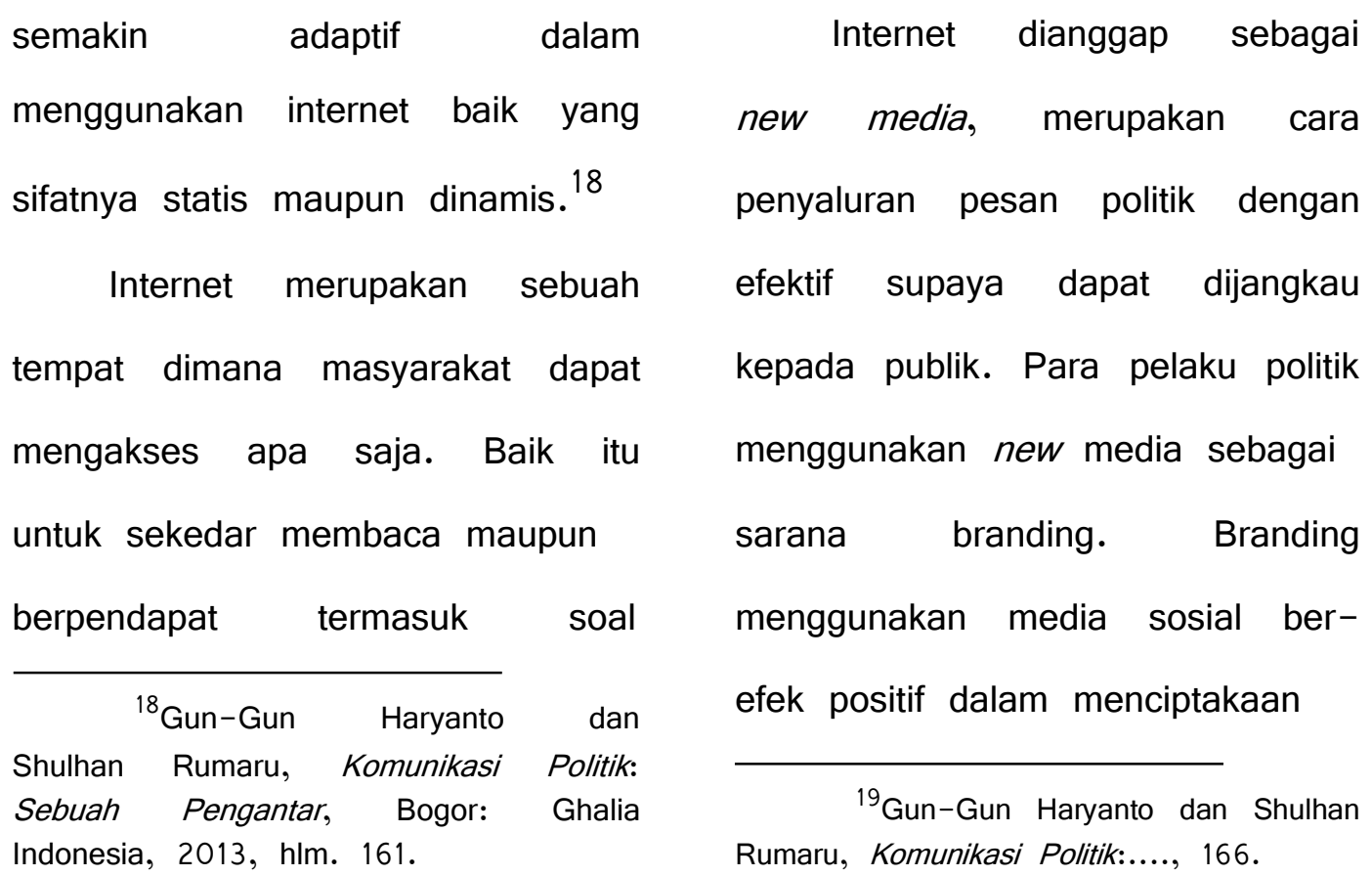


Komunike, Volume XI, No. 2, Desember 2019

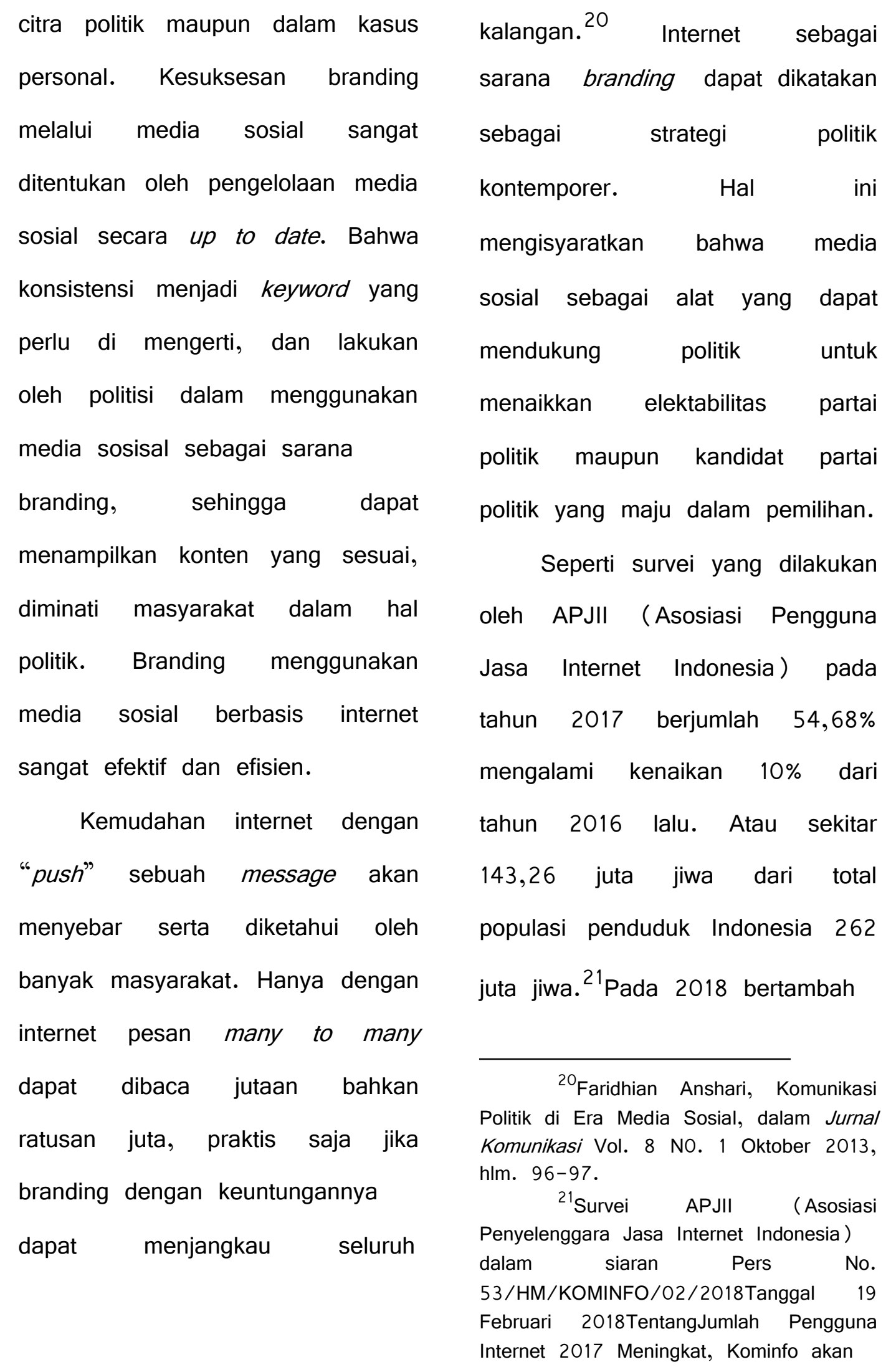


Komunike, Volume XI, No. 2, Desember 2019

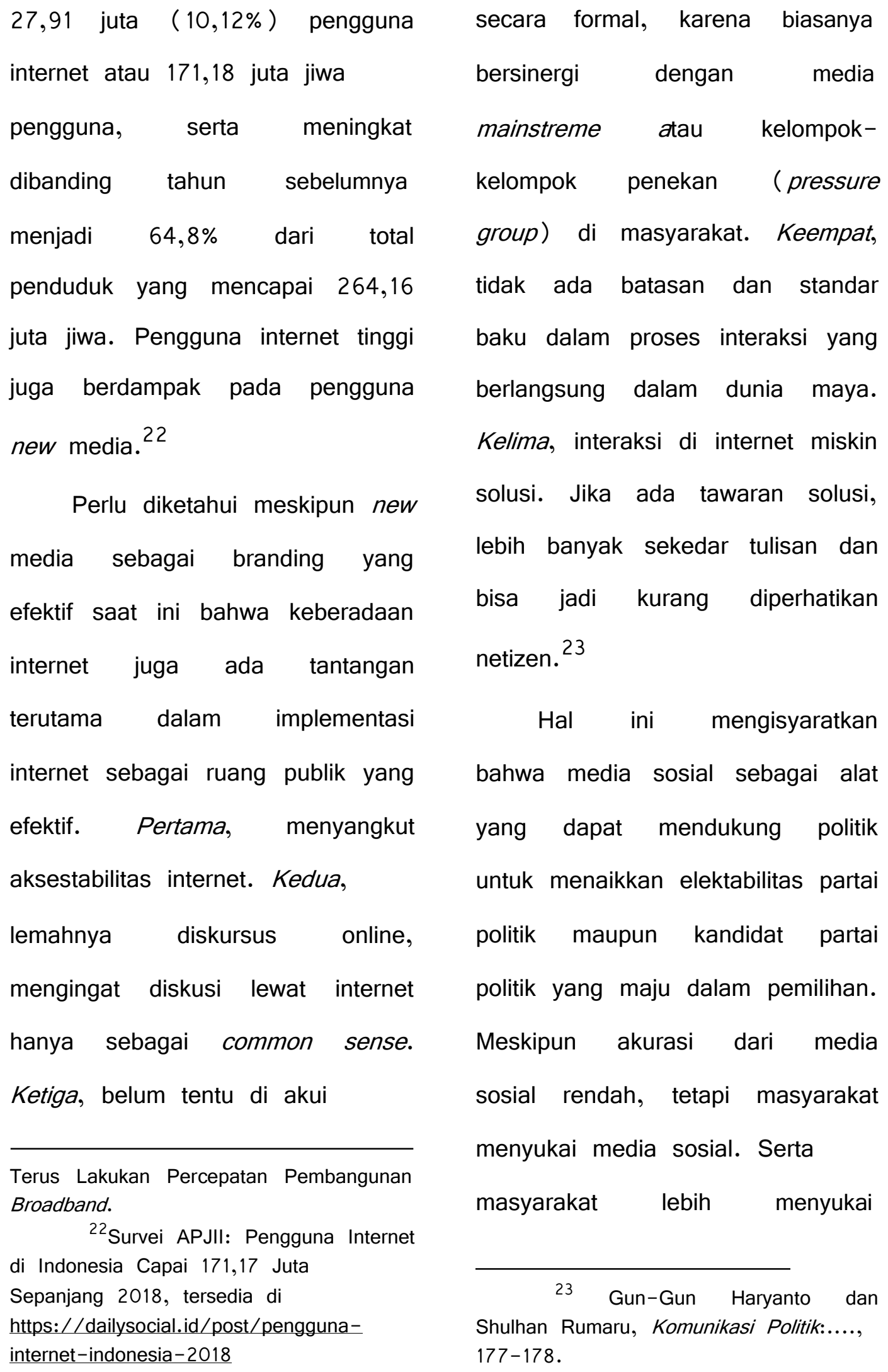


Komunike, Volume XI, No. 2, Desember 2019

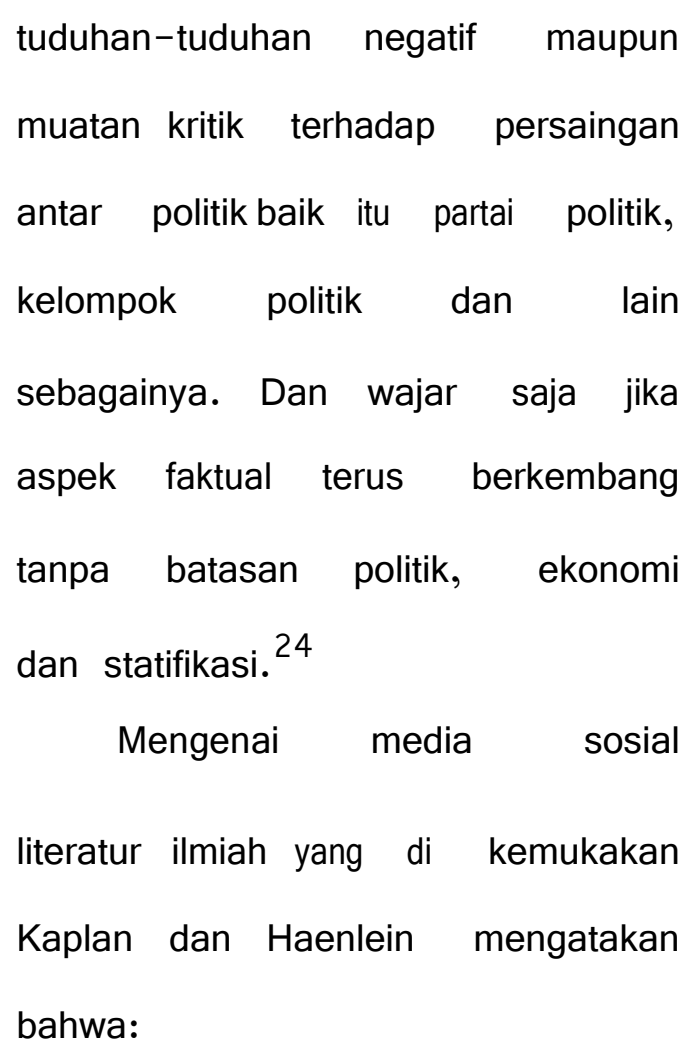

Jejaring sosial dalam konteks

politik sebagai komunikasi politik,

media sosial adalah:

'...web-based Services that allow individuals to (1) construct a public or semi-

\footnotetext{
24 Eko, Hari Susanto, Media

Sosial Sebagai Pendukung Jaringan Komunikasi Politik, Jurnal ASPIKOM, Vol.3 No. 3, Juli 2017, 280.
}

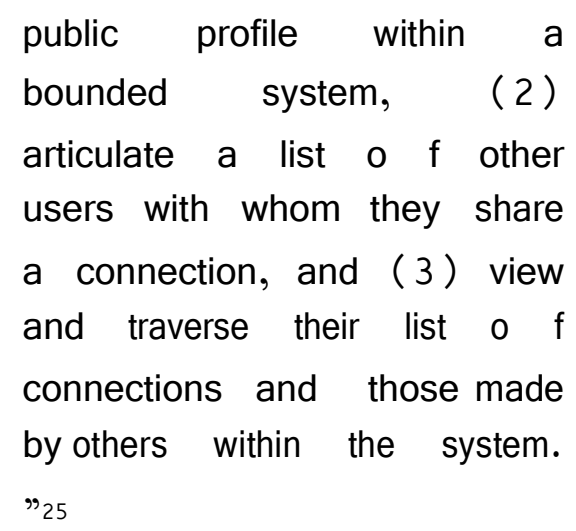

Dari dari hal tersebut dapat dipahami bahwa aplikasi yang berbasis internet dibangun atas fondasi ideologis dan teknologi WEB 2.0. serta layanan berbasis WEB memungkinkan seorang individu untuk membangun profil pada ranah publik dalam sistem, mengartikulasikan daftar pengguna lain dengan siapa mereka berbagi koneksi serta melihat dan melintasi daftar koneksinya. Menempatkan media sosial yang multikompleks bagaimana suatu pesan dikonstruksikan dan bagaimana informasi tersebut di

25 Kaplan dan M. Haenlein,
"Users of the World, Unite! The
Challenges and Opportunities of Social
Media", Business Horizons, Vol. 53,
2010, 61.


Komunike, Volume XI, No. 2, Desember 2019

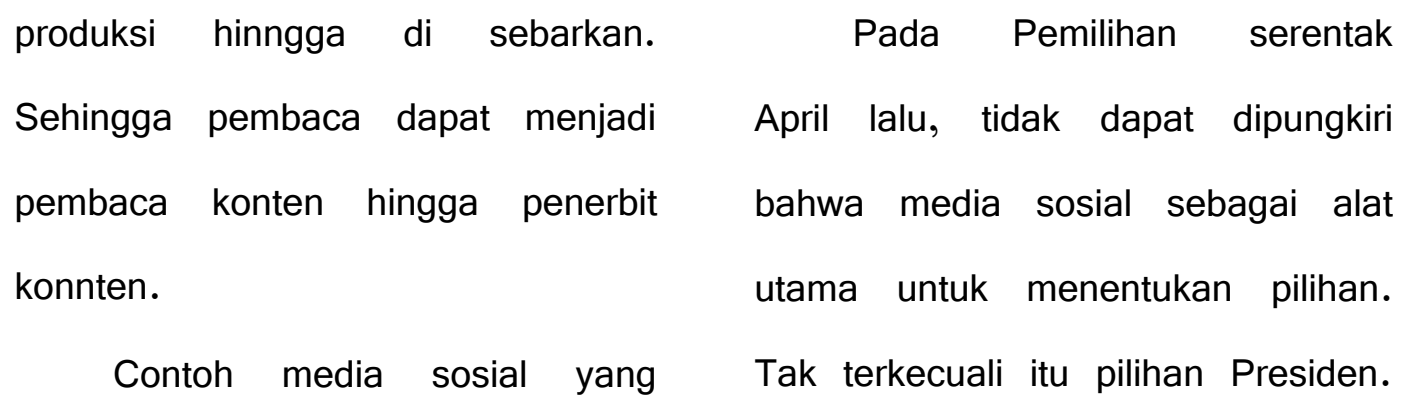
digunakan elit politik untuk Media sosial rame dengan berkampanye Dalam pemilihan bermain tagar hingga peran Gubernur DKI Jakarta tahun 2012 buzzer. Pasangan Jokowi dan silam yang meloloskan Jokowi dan Ma'ruf juga memprodukdi konten Ahok sebagai pemenang. Proses kampanye digital yang di sesuai kampanye hingga branding banyak dengan platform masing-masing. menggunakan media sosial, Seperti Instagram mame dan sehingga tidak salah bila branding video, Twitter dengan dijalankan dengan menggunkaan mengandalkan tagar untuk media sosial adak menuai hasil memenangkan narasi. Hingga yang positif. $^{26}$ Hal serupa juga di Facebook yang cakupannya luas. terapkan oleh Gubernur DKI Seperti tagar andalan Jakarta Anis dan Sandi yang \#01IndonesiaMaju yang head-tomenggunakan media sosial head dengan tagar Facebook dalam berkampanye, \#2019GantiPresiden. Februari supaya generasi muda dapat 2019, jumlahnya mencapai berpartisipasi dalam pilkada. ${ }^{27} \quad 131.839$ cuitan. Disusul tagar

\footnotetext{
${ }^{26}$ Faridhian Anshari, Jurnal Komunikasi, Komunikasi Politik,... 97.

${ }^{27}$ Tresna Yulianti, Tirto.id, dalam manfaatkan-media-sosial-untukhttps://tirto.id/strategi-anies-sandi-
} 
\# JokowiOrangnyaBaik

\#DebatPintarJokowi. ${ }^{28}$

\section{Fungsi Politik Media}

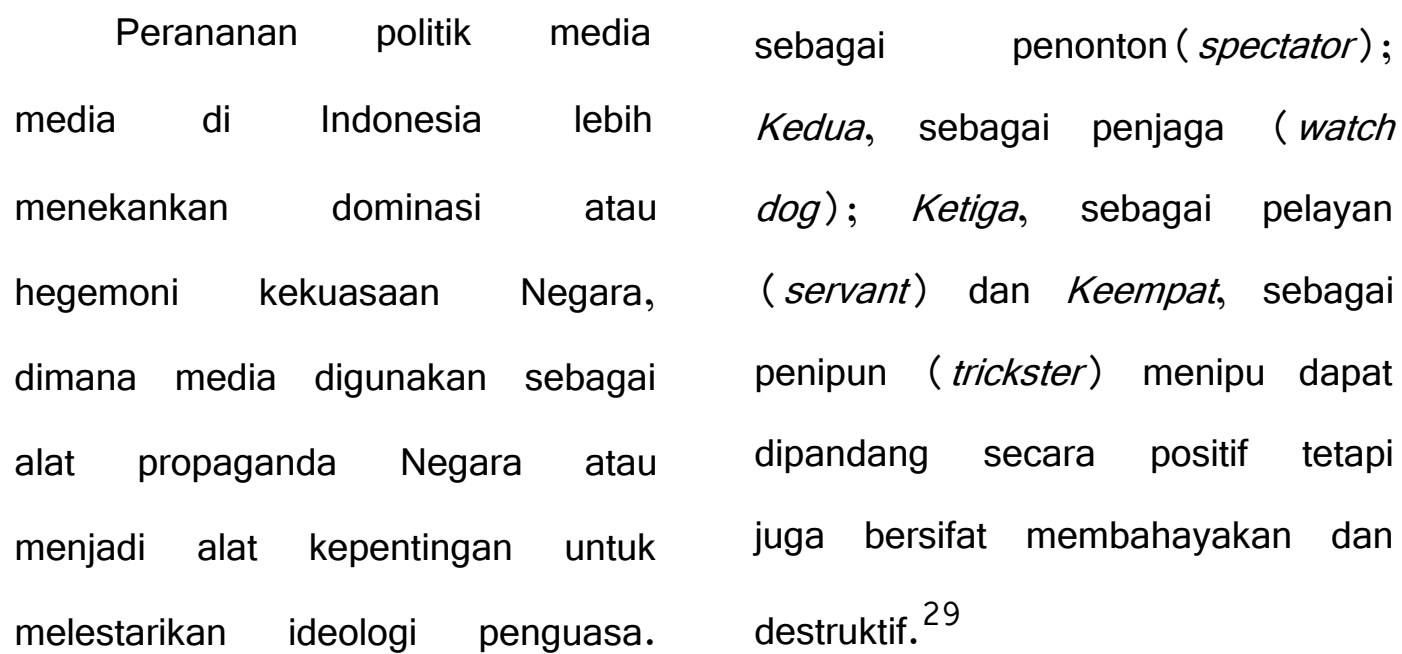

Dalam hal ini kepentingan yang

cukup signifikan dari pemegang

kekuasaan untuk menggunakan

media sebagai alat politik untuk

mencapai tujuannya. Pada

dasarnya media memiliki karkater

yang bermacam-macam. Upaya

mempengaruhi muatan dan nada

dari publikasi pemberitaaan politik

dari media tidak hanya berkaitan

dengan Negara tetapi juga juga

${ }^{28}$ Restu Diantina Putri, Tirto.id

Tersedia di https://tirto.id/membedahstrategi-perang-udara-media-sosialjokowi-maruf-dihq politisi posisi petinggi militer, pihak publik, perusahaan dan lain sebagainya. Bahwa role politik media adalahPertama, media sebagai penonton (spectator); Kedua, sebagai penjaga (watch

Contoh permasalah terkait fungsi dari media adalah hubungan MNC Group milik Harry Tanoesodibjo. Sebagai perusahaan yang tercacat di Bursa Efek Indonesia sebagai perusahaan media dan informasi. Namun ternyata HT memiliki peran terhadap partai yang didirikannya yaitu Perindo. Dalam komunikasi politik apa yang dilakukan HT adalah bentuk kegiatan politik

$$
{ }^{29} \text { Siti, Aminah, Jurnal Unair, }
$$
Politik Media...., 2. 
Komunike, Volume XI, No. 2, Desember 2019

$\begin{array}{lll}\text { untuk membangun simpati, } & \text { media online dengan berbagai } \\ \text { sehingga akan mempengaruhi } & \text { platformny memiliki kalebihan } \\ \text { perolehan suara terhadap } & \text { atau kebebasan tersendiri ketika } \\ \text { partainya. }{ }^{30} & & \text { menyampaikan sikap politik } \\ \text { Optimalisasi fungsi politik } & \text { terhadap lembaga pemerintah. }\end{array}$

media dipengaruhi oleh beberapa

spek seperti: Pertama,

E. Tiga Frame Politik Media keberhasilan pelaksanaan fungsi Sebagai Analisis.

watchdog pers ikut dipengaruhi oleh hubungan yang dekat antara media dan kaum intelektual (challengers) yang menjadi basis penting untuk mejalankan demokrasi media. Kedua, abuse of power politik operasional media tidak hanya datang dari tajuk rencana sebagai sikap politik dari media tetapi juga dari berita utama tanpa harus mengabaikan kaidah-kaidah jurnalistik. Ketiga, dengan pekembangan new media

\footnotetext{
${ }^{30}$ Firdaus Aulia Rahman, M.Fasha Rouf, Fajar Nugraha Asyahidda, Achmad Hufad, "Bias Politik Dibalik Sebuah Media: Relevansi Sosialisasi Politik di Indonesia" Jurnal SOSIETAS, VOL. 8, NO. 2, 2018, 554.
}

1. Politik Media Sebagai Suatu Kebijakan

Politik media sebagai kebijakan dari sebuah negara, menempatkan posisi negara begitu kuat. Atau kebijakan yang melibatkan seluruh unsurunsur dari struktur poitik ( partai, parlemen, pemerintah), baik langsung ataupun tidak langsung mempengaruhi produksi, distribusi, dan konsumsi (penerimaan ) isi informasi dalam masyarakat. 32

\footnotetext{
${ }^{31}$ Salvatore Simarmata, Media \& Politik:...., 205-206.

32 Hermin, Indah Wahyuni, Jurnal IImu Komunikasi, Politik Media,...15.
} 
Komunike, Volume XI, No. 2, Desember 2019

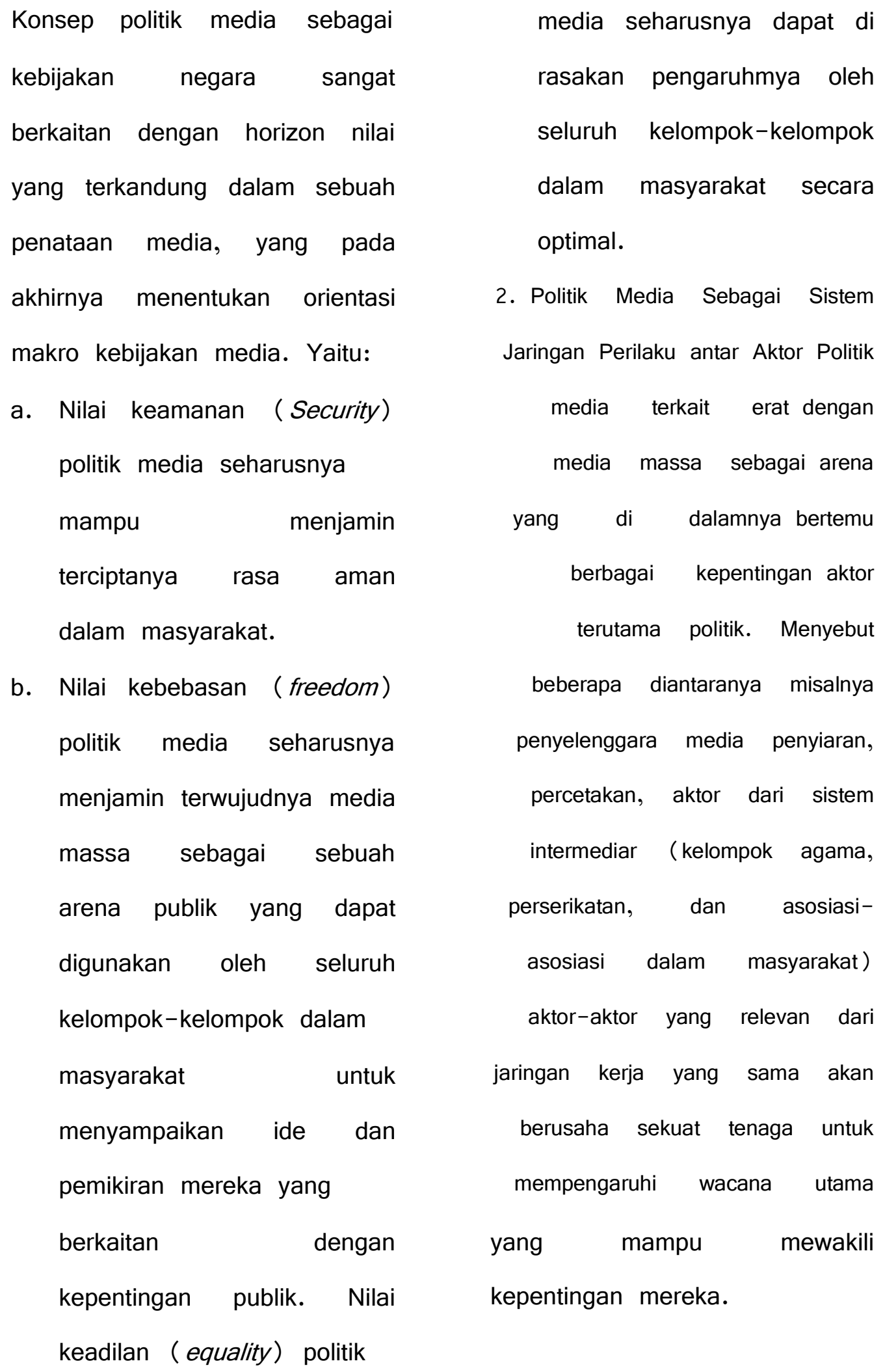


Komunike, Volume XI, No. 2, Desember 2019

Secara umum, politik media dalam konteks ini dipahami sebagai jaringan hubungan antara aktor politik, yang berkepentingan terhadap proses pengembangan wacana dalam sebuah tema tertentu. Artinya masing-masing aktor yang terkait dalam sebuah korporasi tindakan yang relevan satu dengan yang lainnya. ${ }^{33}$

3. Politik Media sebagai arena konvergensi politik.

Politikmediasebagai konvergensi politik merupakan sebuah thesis bahwa media massa tidak lagi dapat dipandang sebagai sebuah bidang yang berdiri sendiri. Melainkan ia berkembang bersama bidang yang lain. Perubahan pada bidang tertentu, misalnya perubahan pada bidang teknologi ataupun

${ }^{33}$ Hermin, Indah Wahyuni, Jurnal IImu Komunikasi, Politik Media,...16. lainnya akan sangat berkaitan degan bidang kebijakan media. Dalam tingkat praxis ini erat kaitannya dalam masalah distribusi siaran, ataupun pengaturan telekomunikasi.

Model politik media sebagai arena konvergensi politik cenderung bersifat sangat normatif. Karena dalam kenyataan politik penyiaran dan politik telekomunikasi dianalisis secara terpisah. Karena dua kebijakan ini memiliki tujuan yang melibatkan institusi serta aktor-aktor yang berbeda. ${ }^{34}$

\section{F. Kesimpulan}

Dari penjelasan diatas, kita dapat melihat potret kehadiran Hizb sebagai fenomena baru dalam sejarah perpolitikan dunia dan terutama kehadiran Hizb di Indonesia dengan isu-isu IImu Komunikasi, Politik Media,...17-18. 
Komunike, Volume XI, No. 2, Desember 2019

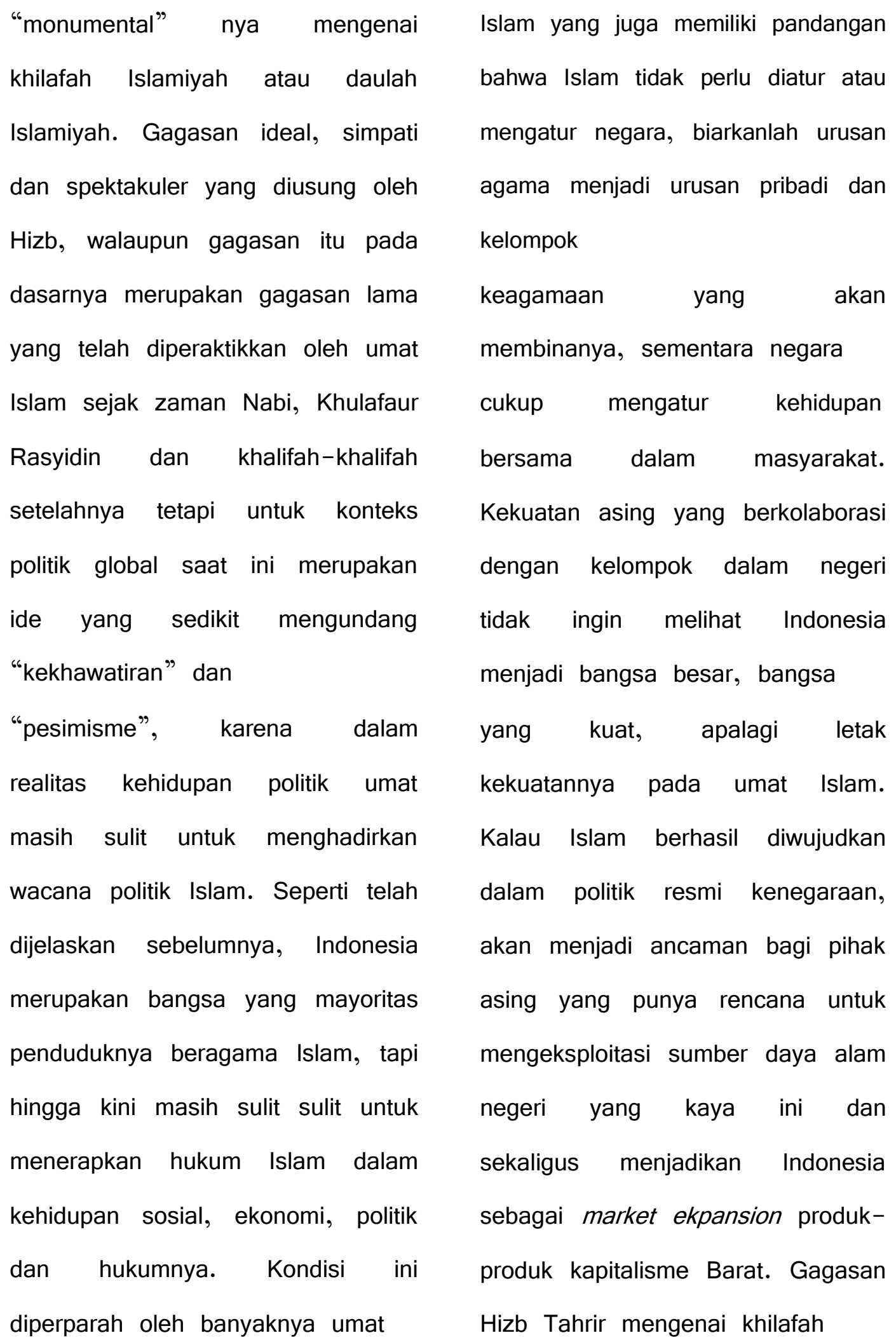


Komunike, Volume XI, No. 2, Desember 2019

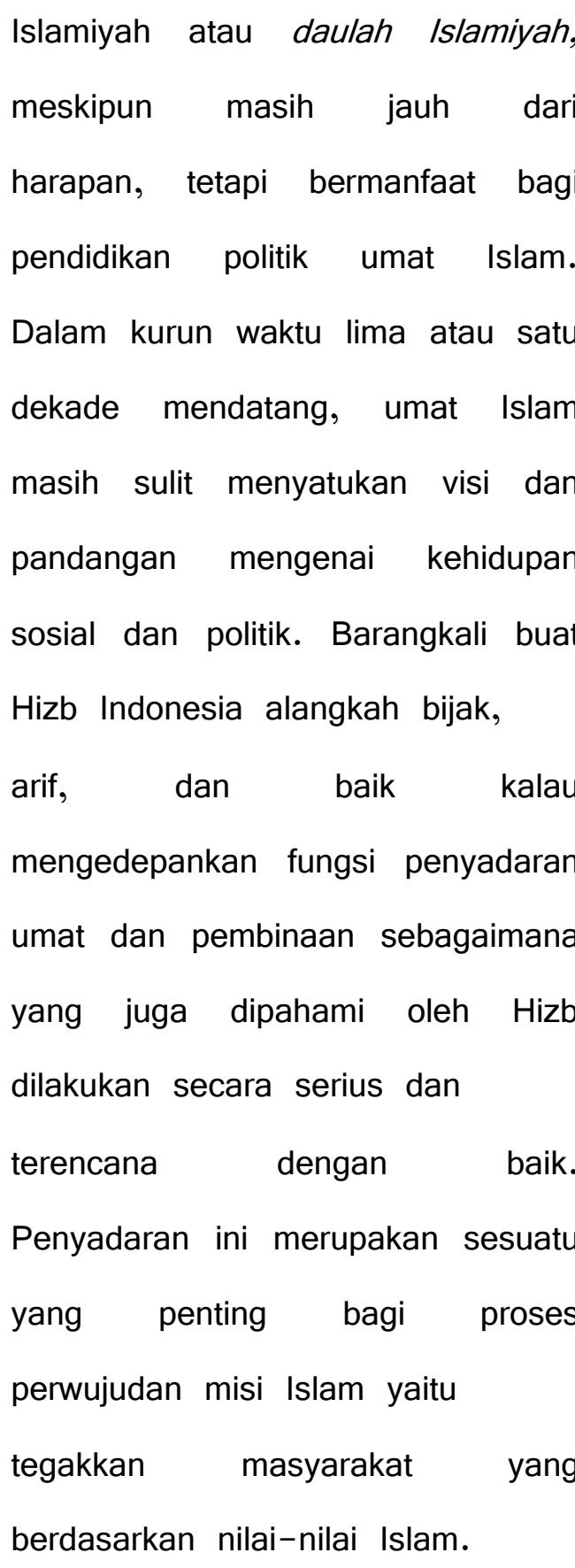

\section{Daftar Pustaka}

Aminah, Siti, Politik Media, "Demokrasi dan Media
Politik", dalam Jurrnal Unair tersedia $\quad \mathrm{di}$ http://journal.unair.ac.id/filterPDF /POLITIK\%2OMEDIA,\%20\%20DEMO KR ASI.pdf.

Anshari, Faridhian, "Komunikasi Politik di Era Media Sosial", dalam Jurnal

Komunikasi, Vol. 8 No. 1 Oktober 2013.

Hermin, Indah Wahyuni, "Politik Media dalam Transisi Politik: Dari Kontrol Negara menuju Self Regulation Machanism", dalam Jurnal IImu Komunikasi, Vol. 04, No. 01, Juni 2007. Heryanto, Gun-Gun dan Shulhan Rumaru. 2013. Komunikasi

Politik:

Sebuah Pengantar, Bogor: Ghalia Indonesia

Kaplan dan M. Haenlein, "Users of the World, Unite! The

$\begin{array}{lll}\text { Challenges } & \text { and } \\ \text { Opportunities of Social }\end{array}$


Komunike, Volume XI, No. 2, Desember 2019

Media", Business Horizons,

Vol. 53, 2010

Sulaiman, Adhi Imam "Dilema Elite

Muldofa, Chisnau. New Media

Politik dan Kekuatan

Dimenssion: Personalization

of Politics Academy, of

Media Massa", Jurnal

MIMBAR, Vol. XXVI, No.

Sciencs and Economic,

Pdf, Tersedia di

resources.perpusnas.go.id

Rahman, Firdaus Aulia, M.Fasha

Rouf, Fajar Nugraha

Asyahidda, Achmad Hufad,

"Bias Politik Dibalik Sebuah

Media: Relevansi Sosialisasi

Politik di Indonesia"

Jurnal SOSIETAS, VOL. 8,

NO. 2, 2018,

Restu Diantina Putri, Tirto.id Tersedia di https://tirto.id/membedah-strategi-

perang- udara-media-

sosial-jokowi-maruf-dihq

Simarmata, Salvatore. 2014. Media

\& Politik: Sikap Pers

Terhadap Pemerintah

Koalisi di Indonesia. Susanto, Eko Hari, "Media Sosial

Jakarta: Yayasan Pustaka

Obor Indonesia.

2, Desember 2010.

$\begin{array}{ll}\text { Survei APJII } & \text { (Asosiasi } \\ \text { Penyelenggara Jasa Internet } \\ \text { Indonesia) dalam siaran } \\ \text { Pers } & \text { NO. }\end{array}$

53/HM/KOMINFO/O2/2018T

anggal $\quad 19 \quad$ Februari

2018TentangJumlah Pengguna

Internet 2017 Meningkat,

Kominfo akan Terus Lakukan

Percepatan

Pembangunan Broadband.

Survei APJII: Pengguna Internet di Indonesia Capai 171,17 Juta

Sepanjang 2018,

$$
\text { tersedia di }
$$

https://dailysocial.id/post/pengguna

-internet-indonesia-2018

Sebagai Pendukung Jaringan

Komunikasi Politik", Jurnal 
Komunike, Volume XI, No. 2, Desember 2019

ASPIKOM, Vol.3 No. 3, Juli Thomas, Tokan Pureklolan. 2016. 2017. Komunikasi Politik:

Tabroni, Roni. "Etika Komunikasi Mempertahankan Integritas Politik dalam Ruang Media Akademisi, Politikus, dan Massa", dalam Jurnal Negarawan, Jakarta: Ilmu Komunikasi, Vol. 10, Gramedia Pustaka Utama. No. 2 Agustus 2012. 